\title{
有机种植对农田节肢动物多样性影响的整合分析
}

\author{
黄方倩，王超，刘明庆®，陈秋会，韩笑®*，王磊 ${ }^{*}$, 席运官，张纪兵
}

生态环境部南京环境科学研究所, 南京 210042

摘要: 有机农业是生态环境友好的生产方式, 对农业生物多样性保护具有重要意义。个体研究的差异不利于有机农业的生态 环境效益评估。本研究利用文献整合分析, 以对农田生态环境具有良好指示作用的节肢动物为研究对象, 探讨了有机种植对 农田生物多样性的保护效果及影响因素。结果表明, 相比常规种植, 有机种植可使节肢动物的丰富度、多度及均匀度显著提 升34.95\%、64.95\%及 $12.09 \%$; 天敌和害虫的物种丰富度分别显著提升了 $22.50 \%$ 和 $31.03 \%$; 同时天敌的个体数量比常规显著增 加了 $71.80 \%$, 害虫减少了 $10.46 \%$ 。经过3年及以上的有机种植后, 节肢动物的丰富度和多度均显著高于常规种植。常规种植 化学农药施用频率可显著影响节肢动物丰富度和均匀度指数, 施药次数每增加 1 次, 节肢动物丰富度相比有机种植显著降低 $13.54 \%$, 均匀度显著降低 $2.64 \%$ 。有机水田对节肢动物多度的提升效果显著优于有机旱地，为后者的 4.7 倍; 但二者的丰富度 和均匀度没有显著差异。蔬菜和茶叶种植体系对节肢动物多样性指数的综合提升效果优于其他作物类型, 丰富度、多度和均 匀度指数分别显著提升了 $81.46 \% 、 74.14 \% 、 18.55 \%$ 和 $48.86 \% 、 49.06 \% 、 30.88 \%$ 。鼓励常规种植减少农药施用频次，加大有 机和生态化管理措施的应用程度，是保护农业生物多样性、实现农业绿色高质量发展的有效途径。

关键词: 农业生物多样性; 有机种植; 常规种植; 节肢动物; 整合分析

黄方倩, 王超, 刘明庆, 陈秋会, 韩笑, 王否, 席运官, 张纪兵 (2022) 有机种植对农田节肢动物多样性影响的整合分析. 生物多样性, 30, 21243. doi: 10.17520/biods.2021243.

Huang FQ, Wang C, Liu MQ, Chen QH, Han X, Wang L, Xi YG, Zhang JB (2022) Effects of organic planting on arthropod diversity in farmland: A meta-analysis. Biodiversity Science, 30, 21243. doi: 10.17520/biods.2021243.

\section{Effects of organic planting on arthropod diversity in farmland: A meta-analysis}

Fangqian Huang, Chao Wang, Mingqing Liu ${ }^{\mathbb{D}}$, Qiuhui Chen ${ }^{\mathbb{D}}$, Xiao Han ${ }^{(\mathbb{D} *}$, Lei Wang*, Yunguan Xi, Jibing Zhang Nanjing Institute of Environmental Sciences, Ministry of Ecology and Environment, Nanjing 210042

\begin{abstract}
Aims: Organic planting is widely considered an environment-friendly agricultural management pattern that plays a crucial role in the protection of agricultural biodiversity. The change of arthropod biodiversity is proposed as a key ecological indicator for agricultural sustainability. However, the effects of organic planting on arthropod biodiversity remain inconsistent in published studies, which may have resulted from the durations of organic planting, land use and cropping systems across the individual studies. The diverse results from previous studies could weaken the practicability of their conclusions in policymaking, which highlighted the necessity of conducting a meta-analysis to provide a generalized understanding of the effects of organic planting on arthropod diversity. This study aims to quantify the impact of organic planting on arthropod biodiversity using meta-analysis and provide scientific support for the formulation of ecological compensation policy under organic planting.

Methods: This meta-analysis conducted a literature review of peer-reviewed papers published before the end of 2020 which compared the impacts of organic and conventional planting on arthropod biodiversity. The results from 75 experimental sites, which contained 227 paired valid datasets, were selected for our analysis. To distinguish between the sources of variation for the responses of biodiversity to organic planting, the paired measurements were further subdivided into subgroups according to the factors of duration, land use, crop variety, pesticide application frequency in conventional planting, and arthropod functional groups.
\end{abstract}

收稿日期: 2021-06-20; 接受日期: 2021-09-22

基金项目: 中央级公益性科研院所基本科研业务专项(GYZX210516)、国家科技支撑计划(2014BAK19B01)和环保公益性行业科研专项(201309036)

* 共同通讯作者 Co-authors for correspondence. E-mail: hxofrcc@126.com; wlofrcc@126.com 
Results: The results showed that compared with conventional planting, organic planting significantly improved the richness, abundance, and evenness of arthropods by the rate of $34.95 \%, 64.95 \%$, and $12.09 \%$, respectively. The abundance of the natural enemies of arthropods increased by $71.80 \%(P<0.05)$ while the abundance of pests decreased by $10.46 \%$ under organic planting. The richness of the natural enemies and pests under organic planting were both increased by $22.50 \%$ and $31.03 \%$ respectively, relative to conventional planting $(P<0.05)$. The application of pesticides significantly decreased the arthropod biodiversity in conventional planting. Compared with the organic planting, an increase in the time of pesticide application in the conventional planting lead to decreases in the arthropod richness and evenness of arthropods by $13.54 \%$ and $2.64 \%$, respectively. The responses of arthropod richness and abundance to organic planting were significantly positive when the duration was equal to or exceeded three years. The positive effect of organic planting on arthropod abundance in paddy fields was 4.7 times higher than that in dryland $(P<0.05)$, but the responses of richness and evenness to organic planting were comparable between paddy and dryland $(P>0.05)$. The responses of arthropod richness, abundance, and evenness to organic planting under the vegetable system were $81.46 \%, 74.14 \%$, and $18.55 \%$, respectively $(P<0.05)$; and under the tea-planting system were $48.86 \%$, $49.06 \%$, 30.88\% $(P<0.05)$, respectively. The benefits of organic planting on arthropod biodiversity under the cropping systems of vegetable and tea were demonstrated to be more significant than that under other cropping systems.

Conclusions: Our meta-analysis suggests that organic planting plays an important role in protecting and improving biodiversity in croplands by increasing the abundance of natural enemies and decreasing pests abundance. The frequency of pesticide application was observed to be the key factor which significantly regulates the change of arthropod biodiversity. To promote the positive effects of organic planting on the protection of biodiversity in cropland, policymakers should not only to encourage the implementation of organic planting in regions where necessary conditions are satisfied, but also facilitate the ecological innovation of conventional planting by introducing the principles, concepts, and technologies of organic planting into conventional planting. This will be of more practical significance to agricultural biodiversity conservation in China.

Key words: agricultural biodiversity; organic planting; conventional planting; arthropod; meta-analysis

农业生物多样性是生物多样性的重要组成部 分, 在保障粮食安全、耕地生态健康和应对气候变 化等方面发挥着重要作用(陈海坚等, 2005; 初炳瑶 等, 2020)。然而, 集约化的农业管理中对化学农药 的大量应用导致的农业生态环境简单化, 已成为农 业生物多样性降低的主要原因之一, 严重制约了农 业的可持续健康发展(Birkhofer et al, 2014; 潘扬等, 2020; 高否等, 2021)。有机种植被认为是生态环境 友好的种植方式, 已在全球范围内大规模推广, 截 至2019年底全球有机农地种植面积达7,230万ha (国 家市场监督管理总局和中国农业大学, 2019)。与常 规种植相比, 有机种植在生产过程中禁止使用化学 合成的农药、化肥、生长调节剂、饲料添加剂等物 质, 采用农作物间作、轮作等农田管理措施以及生 物或物理方式防治病虫害, 有利于农田生态系统的 平衡与修复、降低害虫发生频次, 对保护农业生物 多样性具有重要作用(周子杨, $2011^{1}$; 邢树文等, 2017)。

节肢动物在农田生态系统的传粉、微生物种群

(1) 周子杨 (2011) 不同类型稻田非作物生境的节肢动物多样性. 硕士 学位论文, 南京农业大学, 南京.
调节、有机物分解和生物营养循环中起着重要作用, 影响着农田生物群落结构演替, 是农田生态系统的 重要组成部分(Doles et al, 2001)。因其世代周期短、 直接或间接以植物为食、种群数量巨大等特点, 节 肢动物对栖息地生态环境变化具有良好的指示作 用, 可用作生态系统生物多样性的指示物, 并有学 者建议将其用于生物多样性保护(李巧等, 2006)。近 年来有机农业对生物多样性的影响受到国内外学 者的关注, 其中对节肢动物多样性的研究开展相对 较早(潘扬等, 2020)。但由于不同研究之间受有机种 植年限、种植作物类型以及农田管理措施等客观条 件影响, 结论存在一定差异性。如Morente等(2018) 对不同种植方式下节肢动物的多样性进行研究发 现, 相比常规种植, 有机种植方式下节肢动物的物 种丰富度较高, 但均匀度较低。而张蓉等(2010)对有 机与常规枸杞园中节肢动物群落进行系统调查, 结 果表明, 有机种植园中节肢动物的丰富度、多度以 及均匀度均高于常规种植园。不同研究结果的差异 不利于政府对有机农业生态环境价值的评估。

文献整合分析是将同一主题下的多个独立实 验(研究)进行综合的统计分析方法, 通过增加样本 
量以达到提高统计学检验功效的目的(彭少麟和郑 凤英, 1999; 雷相东等, 2006)。本研究采用此方法定 量分析有机种植对农田节肢动物多样性的影响, 并 从有机种植年限、耕地利用方式、作物种类、常规 种植田农药施用次数以及天敌和害虫功能类群的 角度分析其影响因素差异, 以期在更大的时空尺度 上定量、系统地回答有机种植如何影响节肢动物多 样性, 为有机农业生态环境效益评估提供数据支撑。

\section{1 材料与方法}

\section{1 数据来源}

本研究的数据资料来自中国知网和 Web of Science数据库所收录的有机种植对节肢动物多样 性影响的相关文献，文献出版时间为1980-2020年。 检索关键词为有机农业、有机种植、节肢动物、物 种多样性、生物多样性、 organic agriculture、 organic planting 、 organic farming 、 arthropod 、 biological diversity。根据研究目的, 检出的文献需 符合以下篮选标准: (1)研究基于田间试验, 且试验 同时设置了有机种植处理和常规种植处理; (2)有机 和常规种植处理除农事操作不同外, 作物类型和试 验区域应一致; (3)试验年数应在3年以上(含3年); (4) 节肢动物多样性数据应可以从文献文字、图表中提
取，或者可以通过计算获得; (5)若同一点位的试验 结果发表了多篇文章, 则不重复纳入文献样本。最终, 篮选出符合以上条件的有效文献54篇(附录1), 其中 中文文献27篇, 英文文献27篇; 提取有效数据227组, 共计75个点位试验, 所涉研究区域如表1所示。

本研究从耕地类型、有机种植年限、常规种植 每年杀虫剂的施用次数、种植作物类型以及节肢动 物功能类群, 将试验样本按照不同水平分组(表2), 以期明确有机和常规种植对节肢动物多样性的影 响机制。其中, 常规种植年施药次数指有机种植的 对照处理(常规种植)中每年化学杀虫剂的施用次数; 害虫主要为植食性节肢动物, 天敌包括捕食性和寄 生性节肢动物。

\section{2 数据处理与分析}

采用Margalef丰富度指数 (richness, $R$ )、多度 (abundance, $A$ ) 以及Pielou均匀度指数 (evenness, $E$ ) 作为节肢动物的多样性测度指数 (钱迎倩和马克平, 1994)。其中, 多度(A)用于反映节肢动物群落全部物 种的总个体数(Lichtenberg et al, 2017)。若文献图表 或文字描述中已给出相应指数数值则直接采用, 若 未直接给出但可通过文献结果计算得出, 则通过计 算获取相应指数。Margalef丰富度指数 $(R)$ 用以反映 节肢动物群落的丰富度，计算公式如下:

表1 整合分析纳入的文献所涉及的研究区域分布

Table 1 The distribution of research area contained in the meta analysis

\begin{tabular}{ll||ll}
\hline 样点分布区域(国内) & 试验点位数量 & 样点分布区域(国外) & \multicolumn{1}{c}{ 试验点位数量 } \\
Distribution of research area in China & No. of experimental sites & Distribution of research area outside China & No. of experimental sites \\
\hline 新疆 Xinjiang & 1 & 克罗地亚 Croatia & 1 \\
宁夏 Ningxia & 2 & 巴西 Brazil & 3 \\
四川 Sichuan & 1 & 德国 Germany & 2 \\
贵州 Guizhou & 1 & 法国 France & 1 \\
广西 Guangxi & 2 & 美国 The United States & 14 \\
广东 Guangdong & 葡萄牙 Portugal & 2 \\
湖南 Hunan & 瑞士 Switzerland & 5 \\
江西 Jiangxi & 西班牙 Spain & 3 \\
福建 Fujian & 希腊 Greece & 4 \\
安徽 Anhui & 2 & 意大利 Italy & 1 \\
上海 Shanghai & 2 & 英国 The United Kingdom & 5 \\
江苏 Jiangsu & 2 & & \\
山东 Shandong & 2 & & \\
河北 Hebei & 6 & & \\
北京 Beijing & 2 & & \\
\hline
\end{tabular}


表2 影响因素的不同分组水平

Table 2 Classification of categorical variables as explanatory factors

\begin{tabular}{|c|c|}
\hline 亚组类别 Categorical variable & 亚组水平 Categorical level \\
\hline $\begin{array}{l}\text { 有机种植年限 } \\
\text { Years of organic planting (years) }\end{array}$ & $3-10 、 11-15 、>15$ \\
\hline 耕地类型 Land use & 旱地、水田 Dryland, paddy \\
\hline 作物类型 Crop variety & $\begin{array}{l}\text { 粮食、茶叶、蔬菜、水果、药材、 } \\
\text { 油料 作物 Grain, tea, vegetable, } \\
\text { fruit, crude drug, oil crop }\end{array}$ \\
\hline $\begin{array}{l}\text { 常规种植年施药次数 } \\
\text { Pesticide application frequency } \\
\text { in conventional planting } \\
\text { (times/year) }\end{array}$ & $1-5,6-10 、 11-15 、>15$ \\
\hline $\begin{array}{l}\text { 功能类群 Arthropod } \\
\text { communities }\end{array}$ & 天敌、害虫 Natural enemy, pest \\
\hline
\end{tabular}

$$
R=(S-1) / \ln A
$$

式中, $S$ 为群落内的物种数。

Pielou均匀度指数 $(E)$ 用以反映节肢动物群落中 不同物种的多度分布的均匀程度:

$$
E=H^{\prime} / \ln S
$$

式中, $H^{\prime}$ 为Shannon-Wiener多样性指数, 计算公式如 下:

$$
H^{\prime}=-\sum\left(P_{i} \times \ln P_{i}\right) \quad(i=1,2,3, \cdots, S)
$$

其中, $P_{i}$ 是群落中第 $\mathrm{i}$ 个物种的个体数 $\left(N_{i}\right)$ 与所有物 种个体总数 $(N)$ 的比值。

采用效应值反映实验组相比对照组的变化水 平, 即有机种植相比常规, 其节肢动物多样性指数 的变化水平。本研究采用反应比( $(\operatorname{lnR})$ 来计算效应值 (Rosenberg et al, 2000), 公式如下:

$$
\ln R=\ln \left(X_{e} / X_{c}\right)=\ln X_{e}-\ln X_{c}
$$

式中, $X_{e}$ 和 $X_{c}$ 分别为一个独立研究中实验组和对照 组的平均值。在本研究中, $X_{e}$ 为所获取的一项独立研 究中有机种植处理的Margalef丰富度指数、多度或 Pielou均匀度指数; $X_{c}$ 为常规种植处理的 Margalef丰 富度指数、多度或Pielou均匀度指数。为了更方便 地从生物学角度理解和描述结果, 将反应比通过公 式(5)转换为变化百分率:

$$
V=(\exp (\ln R)-1) \times 100 \%
$$

本研究采用随机效应模型, 利用MetaWin2.1软 件对数据进行整合分析。因并非所有文献都报道了 标准差, 为尽可能多地纳入研究样本, 本研究采用 无权重分析法(Hedges et al, 1999; Chivenge et al, 2011)。运用靴襻法(bootstrapping)重复取样999次来
计算效应值( $\operatorname{lnR}$ )及其95\%置信区间(Rosenberg et al, 2000; 郑凤英等, 2004)。若计算所得效应值均值为 正值则表明有机种植相比常规种植可提高节肢动 物多样性, 若为负值则有机种植相比常规种植降低 了节肢动物的多样性。若效应值的95\%置信区间不 包含 0 , 则此效应显著; 若包含 0 则效应不显著。如 果两项效应值的95\%置信区间没有重叠, 则可认为 这两个因素之间存在显著差异 $(P<0.05)$ (Chivenge et al, 2011)。在亚组分析中, 当组间异质性 $\left(Q_{b}\right)$ 的 $P$ 值小于 0.05 时，效应值在各因素水平之间存在显著 差异。

本研究采用SPSS 20.0对节肢动物多样性的变 化量与常规种植年施药次数进行回归分析, 使用 GetData软件提取文献图中的数据, 采用 Origin 2019软件作图。

\section{2 结果}

\section{1 有机种植对节肢动物生物多样性指数的影响}

本研究从篎选后的54篇文献中提取了 82 组有 机种植与常规种植节肢动物丰富度数据, 90组多度 数据以及 52 组均匀度数据(图1)。与常规种植相比,

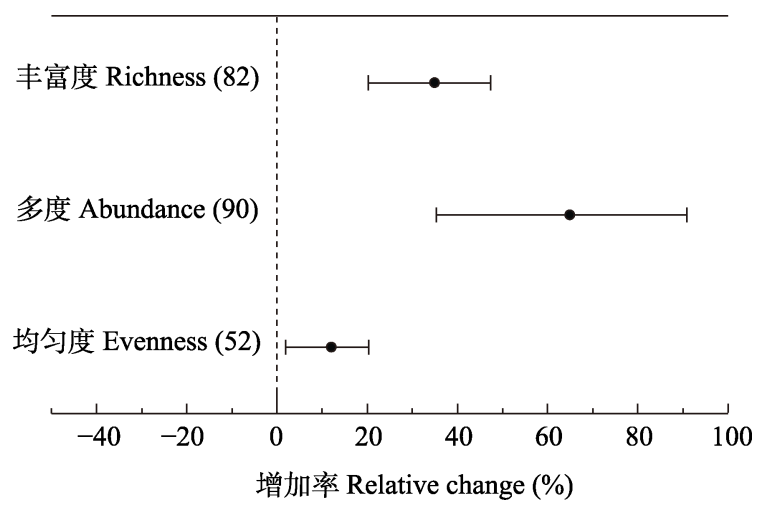

图1 有机种植相比常规种植节肢动物多样性指数的增加 率。图中圆点为效应值, 即有机种植相比常规种植其节肢动 物多样性指数的变化量, 误差线为效应值的 $95 \%$ 置信区间, 括号内的数值为该效应值的样本量。若效应值的 $95 \%$ 置信区 间未跨越零轴, 则表示该效应与对照相比差异显著。

Fig. 1 The relative change of arthropod biodiversity under organic planting compared with conventional planting. The dots in the figure are the mean effect sizes, which represent the relative change of arthropod diversity under organic planting compared with conventional planting. The error lines indicate the $95 \%$ confidence interval (95\% CIs) of the mean effect sizes, and the value in brackets is the sample size. Mean effect sizes were considered to be significantly different from the control if their 95\% CIs did not cross the zero axis. 
有机种植方式下农田节肢动物的丰富度、多度及均 匀度指数均有显著提升 $(P<0.05)$, 分别为 $34.95 \%$ 、 $64.95 \%$ 及 $12.09 \%$ 。

\section{2 不同影响因素下节肢动物丰富度指数对有机 种植的响应}

由图2A可知, 3 年以上的有机种植均可显著提 升节肢动物的丰富度; 随有机种植年限的增加, 节 肢动物丰富度效应值呈现降低的趋势。当种植年限 为3-10年时, 有机种植节肢动物丰富度比常规种植 高37.54\%; 种植年限为11-15年时, 有机比常规高 $28.15 \%$; 大于 15 年时为 $16.07 \%$, 有机对节肢动物丰 富度的提升水平不足 3-10年的 $1 / 2$; 但不同时期的 效应值差异不显著 $(P>0.05)$ 。在水田或者旱地上进 行有机种植, 节肢动物丰富度指数均得到了显著提 升, 但耕地类型对提升程度的影响无显著差异 $(P>$ 0.05)。种植不同作物类型时节肢动物丰富度对有机 种植的响应水平为蔬菜 $>$ 茶叶 $>$ 粮食 $>$ 水果 $>$ 油料作物 > 药材。其中, 蔬菜(81.46\%)显著高于油 料作物 $(14.66 \%)$ 和药材 $(4.91 \%)(P<0.05)$; 作物类 型为茶叶时, 其效应值 (48.86\%)是粮食 (25.56\%)和 水果作物(19.54\%)的1.9和2.5倍, 但差异不显著 $(P>$ 0.05)。

有机种植相比常规种植对节肢动物丰富度指 数的提升效果与常规种植农药的施用次数密切相 关。当常规种植年施药次数在1-5次时, 有机种植可 使节肢动物丰富度提升 $14.50 \%$; 施药次数为 6-10 次、11-15次时，效应值分别为33.65\%和 $35.80 \%$; 常 规种植年施药次数 > 15次时, 有机种植对丰富度 的提升作用可达 $220.63 \%$, 分别是年施药1-5次和 6-10次分组的15.2倍和6.5倍(图2A, $P<0.05$ )。回归 分析结果表明, 常规种植年施药次数能解释 $63 \%$ 的 节肢动物丰富度效应值的变异水平; 常规种植年施 药次数每增加 1 次, 其节肢动物丰富度指数相比有 机种植降低13.54\% (图3, $R^{2}=0.63, P<0.01$ )。

2.3 不同影响因素下节肢动物多度指数对有机种 植的响应

相比常规种植, 3 年以上的有机种植均可显著 提升节肢动物的多度; 种植年限为11-15年时, 节 肢动物多度指数效应值 (87.79\%) 高于 3-10 年 (50.31\%)和> 15年(61.67\%), 但不同年限之间差异 不显著 $(P>0.05)$ 。在水田上进行有机种植, 节肢动
物多度指数的提高幅度 (194.08\%)显著高于旱地 (41.30\%, $P<0.05)$, 约为旱地的 4.7 倍。种植不同作 物类型时节肢动物多度对有机种植的响应水平为 粮食 $(86.37 \%)>$ 蔬菜(74.14\%) > 茶叶 $(49.06 \%)>$ 油料作物(37.82\%) > 水果(22.38\%), 但水果及油料 作物对节肢动物多度指数的提升效果不显著 $(P>$ $0.05)$ 。当常规种植年施药次数 $<15$ 次时, 相应有机 种植田的节肢动物多度指数比常规种植显著提高 36.08\%-92.50\%; 值得注意的是，当常规种植年施 药次数大于 15 次时, 有机种植方式对节肢动物多度 的提升作用并不显著 $(P>0.05)$ (图2B)。

\section{4 不同影响因素下节肢动物均匀度指数对有机 种植的响应}

年限小于 15 年时有机种植对节肢动物均匀度 的提升作用并不显著 $(P>0.05)$, 大于15年时可使均 匀度指数显著提高 $22.01 \%$ 。在水田上进行有机种植, 节肢动物均匀度的效应值有高于旱地的趋势, 但差 异不显著。种植不同作物类型时节肢动物均匀度对 有机种植的响应水平为茶叶 $(30.88 \%)>$ 蔬菜 $(18.55 \%)>$ 水果 $(13.92 \%)>$ 药材 $(12.15 \%)>$ 粮食 $(4.09 \%)>$ 油料作物 $(-3.89 \%)$, 但水果、粮食和油料 作物对有机种植的响应不显著 $(P>0.05)$ 。当常规种 植年施药次数小于 11 次时, 有机种植对节肢动物均 匀度无显著影响; 大于 11 次时, 则节肢动物均匀度 指数显著提高 $24.48 \%-37.07 \%(P<0.05)$ (图2C)。由 回归分析可知，常规种植年施药次数能解释 $33 \%$ 的 节肢动物均匀度效应值的变异水平; 常规种植年施 药次数每增加 1 次, 其节肢动物的均匀度相比有机 种植模式会降低 $2.64 \%$ (图4, $R^{2}=0.33, P<0.01$ )。

\section{5 不同功能类群节肢动物多样性指数对有机种} 植的响应

根据文献描述和物种取食习性将获取的节肢 动物样本划分为天敌类群和害虫类群, 分析其丰富 度和多度指数对有机种植的响应，结果表明(表3), 有机种植相比常规种植, 天敌和害虫的丰富度指数 分别提升了 $22.50 \%$ 和 $31.03 \%$, 害虫丰富度提升程度 虽高于天敌, 但二者差异不显著 $(P=0.45)$ 。有机种 植相比常规种植, 天敌的多度指数显著提升了 $71.80 \%$, 害虫则降低了 $10.46 \%$, 且二者差异显著 $(P$ $=0.001)$ 。因此, 相比常规种植, 采用有机种植的管 理方式可显著提升节肢动物种群的多样性和天敌 
A

有机种植年限
Years of organic planting (years)

B

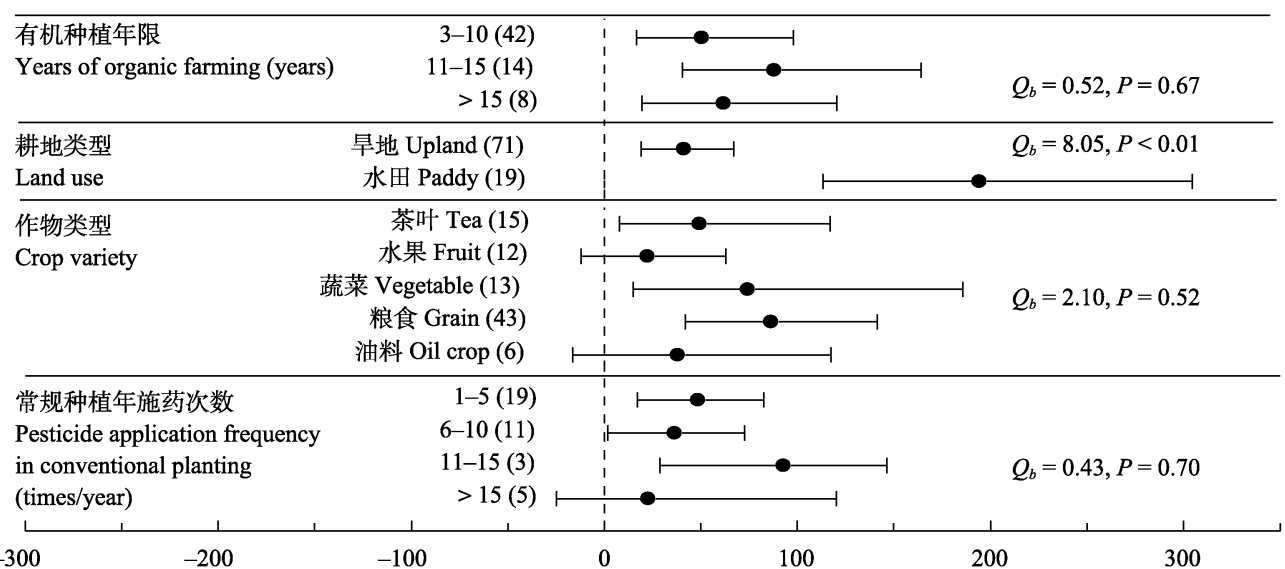

C

\begin{tabular}{|c|c|c|c|}
\hline $\begin{array}{l}\text { 有机种植年限 } \\
\text { Years of organic farming (years) }\end{array}$ & $\begin{array}{r}3-10(22) \\
11-15(9) \\
>15(2)\end{array}$ & 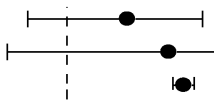 & $Q_{b}=0.04, P=0.86$ \\
\hline 耕地类型 & ad (41) & $\longmapsto$ & \\
\hline
\end{tabular}

Land use

作物类型

Crop variety

田 Paddy (11) 水果 Fruit (5)

水果 Fruit (5)
蔬菜 Vegetable (11)

粮食 Grain (22)

药材 Crude drug (2)

油料 Oil crop (3)

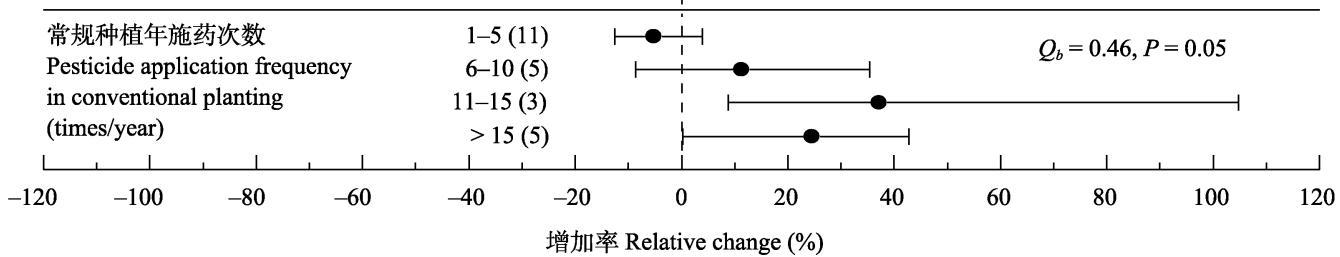

图2 有机种植相比常规种植对节肢动物丰富度(A)、多度(B)、均匀度(C)指数的增加率。图中圆点为效应值, 即有机种植相 比常规种植节肢动物多样性指数的相对变化百分率, 误差线为效应值的 $95 \%$ 置信区间, 括号内的数值为该效应值的样本量。 若效应值的 $95 \%$ 置信区间未跨越零轴，则表示该效应与对照相比差异显著; 若亚组内不同水平的效应值95\%置信区间未重 叠, 则说明分类水平的差异显著。 $Q_{\mathrm{b}}$ (组间异质性)和 $P$ 值用来描述不同水平分类因素多样性指数效应值的统计学差异。

Fig. 2 The relative change of arthropod richness (A), abundance (B), and evenness (C) under organic planting compared with conventional planting. The dots in the figure are the mean effect sizes, which represent the relative change of different diversity index (\%) under organic planting compared with conventional planting. The error lines indicate the 95\% confidence interval (95\% CIs) of the mean effect sizes, and the value in brackets is the sample size. Mean effect sizes were considered to be significantly different from the control if their 95\% CIs did not cross the zero axis, and were considered to be significantly different if their 95\% CIs did not overlap. Between-group heterogeneity $\left(Q_{b}\right)$ and the probability $(P)$ were used to describe statistical differences in the diversity index responses between different levels of the categorized factors. 


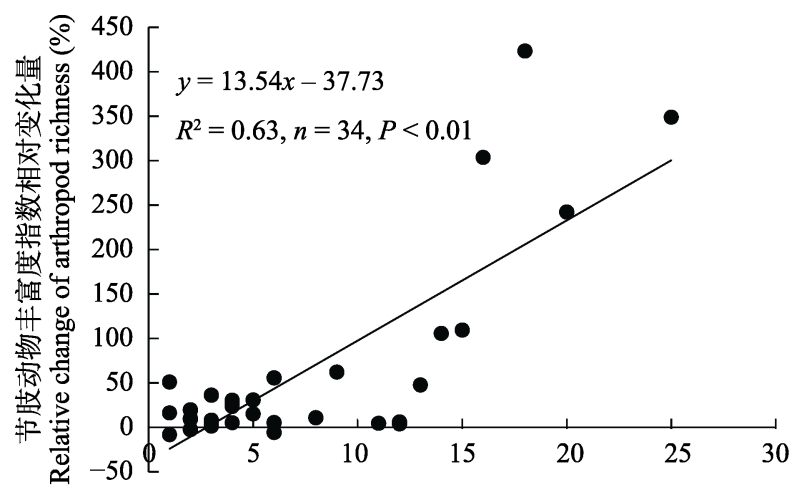

常规种植年施药次数

Pesticide application frequency in conventional planting (times/year)

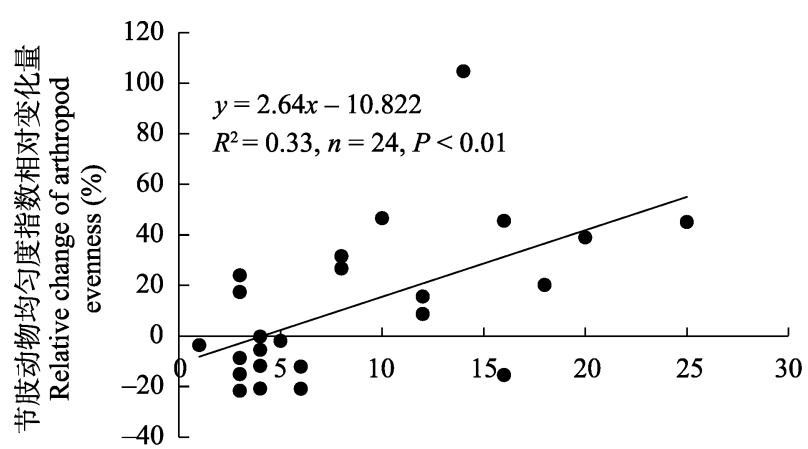

常规种植年施药次数

Pesticide application frequency in conventional planting (times/year)

图3 有机种植相比常规种植节肢动物丰富度指数相对变化量 与常规种植年施药次数的回归分析

图4 有机种植相比常规种植节肢动物均匀度指数相对变化 量与常规种植年施药次数的回归分析

Fig. 3 The relationship between the relative changes of Fig. 4 The relationship between the relative changes of arthropod richness under organic planting compared with arthropod evenness under organic planting compared with conventional planting and the pesticide application frequency in conventional planting and the pesticide application frequency in conventional planting

conventional planting

表3 节肢动物害虫和天敌功能群多样性指数对有机种植的响应

Table 3 Responses of arthropod pest and natural enemy subcommunities diversity to organic planting over conventional planting

\begin{tabular}{lllllll}
\hline $\begin{array}{l}\text { 多样性指数 } \\
\text { Diversity index }\end{array}$ & $\begin{array}{l}\text { 功能类群 } \\
\text { Arthropod communities }\end{array}$ & $\begin{array}{l}\text { 总效应值 } \\
\text { Total effect size (\%) }\end{array}$ & $\begin{array}{l}\text { 95\%置信区间 } \\
\text { 95\% confidence interval (\%) }\end{array}$ & $\begin{array}{l}\text { 样本量 } \\
\text { Sample size }(n)\end{array}$ & $\begin{array}{l}\text { 组间异质性 } \\
\text { Between-group } \\
\text { heterogeneity }\left(Q_{b}\right)\end{array}$ & $\begin{array}{l}\text { 显著性差异 } \\
\text { Probability }(P)\end{array}$ \\
\hline 丰富度 & 天敌 Natural enemy & 22.50 & $13.76-33.62$ & 40 & 0.81 & 0.45 \\
Richness & 害虫 Pest & 31.03 & $9.22-53.18$ & 18 & & 0.001 \\
\multirow{2}{*}{$\begin{array}{l}\text { 多度 } \\
\text { Abundance }\end{array}$} & 天敌 Natural enemy & 71.80 & $45.25-105.15$ & 49 & 5.82 & \\
\hline
\end{tabular}

的数量，同时抑制害虫种群数量，降低了害虫种群 数量暴发的几率。由于提取的样本中仅有 5 组为天 敌均匀度数据, 且未收集到害虫均匀度数据, 因此 没有对天敌和害虫的均匀度指数对有机种植的响 应情况进行分析。

\section{3 讨论}

本研究表明, 相比常规种植, 有机种植能维持 较高的节肢动物丰富度、多度及均匀度, 有利于节 肢动物群落稳定性的提高和多样性的保护, 这与 Lichtenberg等(2017)的研究结论一致。有机种植过 程中禁止使用化学农药, 对农田生态系统的恢复能 力与保护作用均显著高于常规农业。常规集约化农 业中对化学农药(杀虫剂)的不合理施用会显著降低 节肢动物的物种丰富度, 甚至导致部分物种灭绝 (侯有明等, 2001)。孔建等(2001)研究发现, 果园常 用化学杀虫剂对节肢动物中瓢虫、中华草蛉
(Chrysopa sinica) 等天敌幼虫的作用是毁灭性的, 会造成70\%-90\%的虫卵无法孵化。常规农业的施药 次数频繁, 加重了对农田生态系统的人为干扰, 导 致节肢动物群落结构不稳定及个体数量下降。张清 泉等(2014)研究表明, 外界干涉越频繁, 对农田节 肢动物的分布及多样性越不利, 致使节肢动物结构 趋于单一化。本研究结果显示, 只要施用化学农药, 常规种植下节肢动物的丰富度指数就会显著降低; 施药次数每增加 1 次, 常规种植节肢动物丰富度相 比有机种植减少 $13.54 \%$, 均匀度降低 $2.64 \%$ 。施药次 数若大于 11 次/年, 常规种植的节肢动物均匀度相 比有机种植会显著降低; 若超过15次/年, 常规种植 下节肢动物丰富度指数相比有机种植急剧降低, 降 低程度分别是年施药水平1-5次和6-15次的15倍和 6倍。值得注意的是, 对照处理农药施用 $>15$ 次/年时, 有机种植对节肢动物多度指数的提升作用不再显 著, 可能是由于常规田块耐药性强的害虫种群暴发, 
导致常规种植节肢动物个体数高于不施用任何化 学农药的有机种植(张翼噮和唐振华, 2005; 李浩, $2010^{(1)}$ )。德国的一项研究表明, 施用农药对植食性 节肢动物多度的抑制效果仅能维持两周, 在小麦生 育季后期害虫种群密度甚至高于喷施农药之前, 而 捕食性节肢动物的多度则显著低于不施用农药的 常规小麦(Krauss et al, 2011)。因此, 保护农田生态 系统生物多样性, 一方面要推行有机的管理方式, 另一方面在常规种植的管理中应尽可能地减少对 农药的施用, 建议不超过15次/年, 最好控制在11次/ 年以下。

随着农业生物多样性保护越来越受到国际社 会的重视, 采用有机农业的理念和技术对常规农业 进行生态化改造在农业发达国家和地区被广泛接 受和推广(Bommarco et al, 2013)。如英国南部的常 规小麦采用生态化措施防治害虫, 减少了农药的使 用, 由此降低了与有机农场节肢动物多样性的差距 (Moreby et al, 1994); 印度政府大规模推行不施用 任何农用化学品的“零预算自然农业”(高磊等, 2021), 德国和荷兰鼓励农民建立多种类型的人工 播种的农田边缘带(Marshall et al, 2002)等。目前我 国农业生产中对绿肥种植、作物多样化栽培以及非 作物生境维护等有机措施的重视和应用程度相比 农业发达国家还有一定差距。在实际生产中, 集约 化农业往往大面积种植单一作物, 作物生境趋于同 质化; 滥用除草剂导致非作物生境的杂草和蜜源植 物等植被多样性大大降低(Fritch et al, 2017)。有机 农业重视作物的间套作和绿肥轮作, 提倡保留一部 分杂草, 引入和镶嵌植物篱笆及灌木丛来区分农田 的不同区域, 这些措施增加了有机农田生境中的植 被多样性, 为天敌的繁殖、取食等提供了多样化的 栖息环境, 保障了农田生态系统中天敌种群的丰富 度和数量(Altieri, 1999), 有利于农业害虫的生态化 防治。本研究结果也显示有机种植模式下天敌和害 虫的丰富度均有显著提升, 天敌多度比常规种植显 著提高了 $71.80 \%$, 而害虫多度则下降了 $10.46 \%$ 。大 量研究表明, 景观异质性和生境多样性对节肢动物 多样性有重要影响(Letourneau et al, 2011; Han et al, 2014)。如有机葡萄园通过构建多样化的行间植被,

(1) 李浩 (2010) 有机果园与非有机果园节肢动物群落结构及多样性比 较. 硕士学位论文, 天津师范大学, 天津.
蜘蛛种类的丰富度显著高于常规葡萄园(Kolb et al, 2020); 冬闲时种植紫云英的水稻田，其蜘蛛群落多 度明显高于闲田-水稻田(袁伟等, 2010); 在棉田套 种玉米、高粱等诱集棉铃虫产卵的作物, 使其集中 产卵，有利于集中诱杀和保护天敌(陆萍等, 2004)。 本研究中有机水田的节肢动物多度显著高于有机 旱地, 可能是由于相比旱地, 水田的非作物生境增 加了环境异质性、提高了稻田生态系统中的生境多 样性与复杂性(刘雨芳等, 2000; 周子杨, 2011 ${ }^{\circledR}$ )。非 作物生境中的植被或杂草可为一些同翅目(如蚜虫) 和鞘翅目(如甲虫和象虫)害虫生长和发育提供食物 及避难场所(俞晓平等, 1996), 同时，也为有益节肢 动物(如天敌、授粉昆虫)提供了替代猎物或寄主、 营养来源和庇护场所(毛润乾等, 2000)。因此, 在农 业生产过程中, 维护生境的植物多样性对保护节肢 动物的群落多样性具有重要的作用。

从作物类型来看, 在蔬菜和茶叶作物种植体系 上进行有机种植, 对节肢动物多样性指数的综合提 升效果优于其他作物类型, 尤其是蔬菜。相比常规 种植, 有机菜园节肢动物丰富度、多度和均匀度指 数显著提升了 $81.46 \% 、 74.14 \% 、 18.55 \%$, 有机茶园 显著提升 $48.86 \% 、 49.06 \% 、 30.88 \%$ 。近年来我国有 机产业呈现快速、稳定的发展态势, 根据《中国有 机产品认证与有机产业发展(2019)》, 我国有机种植 面积从2005年的46.4万ha上升到2019年的221.5万ha, 增加了约4.8倍, 而其中有机茶叶和蔬菜的种植面 积仅为 6.6 万ha和 3.7 万ha, 仅占总有机种植面积的 $2.98 \%$ 和 $1.67 \%$ 。2018年有机茶种植面积占全国茶叶 总种植面积的 $2.38 \%, 2019$ 年有机蔬菜占全国蔬菜 总种植面积的 $0.08 \%$ (http://zdscxx.moa.gov.cn: 8080/nyb/pc/frequency.jsp), 蔬菜和茶叶的有机种植 面积还存在巨大的增长空间。在蔬菜和茶叶这两种 作物体系中优先推行有机生产, 树立农田生物多样 性保护的样本和典型, 可对农田生物多样性起到示 范和推动作用。

总体来说, 有机种植显著提升了农田节肢动物 多样性指数, 有助于促进农田害虫的生态化防治。 在常规种植中加大对有机和生态化管理措施如减 少农药施用、维持生境植物多样性等的应用程度,

(2) 周子杨 (2011) 不同类型稻田非作物生境的节肢动物多样性. 硕士 学位论文, 南京农业大学, 南京. 
对保护农业生物多样性具有重要的现实意义。我国 应完善以绿色生态为导向的农业生态治理补贴制 度, 通过加强生态保护补偿等相关政策引导农业生 产方式的绿色转型, 以实现保障粮食安全和保护农 业生物多样性的双赢目标。本文未对有机种植下节 肢动物多样性提升的经济效益进行定量核算, 后续 研究可从采用有机管理措施所节约的以及额外支 付的成本、授粉昆虫及天敌的增加带来的经济效益 等角度进行生态成本与收益的核算和探讨, 为生态 补偿政策的制定提供参考。

致谢: 对纳入本文的文献研究的各位作者表示诚挚 的感谢; 感谢南京师范大学李鹏副教授、河北工程 大学张旭珠博士对本文写作内容的指导; 感谢编辑 部和审稿专家在审稿过程中所提出的宝贵意见!

\section{ORCID}

刘明庆 (D) https://orcid.org/0000-0001-5448-8273

陈秋会 (D) https://orcid.org/0000-0002-1008-6157

韩笑 (D) https://orcid.org/0000-0003-3277-3342

\section{参考文献}

Altieri MA (1999) The ecological role of biodiversity in agroecosystems. Agriculture, Ecosystems \& Environment, 74, 19-31.

Birkhofer K, Ekroos J, Corlett EB, Smith HG (2014) Winners and losers of organic cereal farming in animal communities across central and northern europe. Biological Conservation, 175, 25-33.

Bommarco R, Kleijn D, Potts SG (2013) Ecological intensification: Harnessing ecosystem services for food security. Trends in Ecology \& Evolution, 28, 230-238.

Chen HJ, Huang ZF, Li RB, Peng ZB, Mai QF, Jiang JS (2005) Connotation, function and conservation of agriculture biological diversity. Journal of South China University of Tropical Agriculture, 11(2), 24-27. (in Chinese) [陈海坚, 黄昭奋, 黎瑞波, 彭宗波, 麦全法, 蒋菊生 (2005) 农业 生物多样性的内涵与功能及其保护. 华南热带农业大学 学报, 11(2), 24-27.]

Chivenge P, Vanlauwe B, Six J (2011) Does the combined application of organic and mineral nutrient sources influence maize productivity? A meta-analysis. Plant and Soil, 342, $1-30$.

Chu BY, Chen FJ, Ma ZH (2020) Principles of using agricultural biodiversity to control pests and crop diseases. Chinese Journal of Applied Entomology, 57, 28-40. (in Chinese with English abstract) [初炳瑶, 陈法军, 马占鸿
(2020) 农业生物多样性控制作物病虫害的方法与原理. 应用昆虫学报, 57, 28-40.]

Doles JL, Zimmerman RJ, Moore JC (2001) Soil microarthropod community structure and dynamics in organic and conventionally managed apple orchards in western Colorado, USA. Applied Soil Ecology, 18, 83-96.

Fritch RA, Sheridan H, Finn JA, McCormack S, Ó hUallacháin D (2017) Enhancing the diversity of breeding invertebrates within field margins of intensively managed grassland: Effects of alternative management practices. Ecology and Evolution, 7, 9763-9774.

Gao L, Wang L, Hu FL, Yang LR (2021) Recent progress of agro-biodiversity conservation and implications for agricultural development in China. Biodiversity Science, 29, 177-183. (in Chinese with English abstract) [高䂞, 王蕾, 胡飞龙, 杨礼荣 (2021) 农业生物多样性保护履约进展 及对我国农业发展的启示. 生物多样性, 29, 177-183.]

Han P, Niu CY, Desneux N (2014) Identification of top-down forces regulating cotton aphid population growth in transgenic Bt cotton in central China. PLoS ONE, 9, e102980.

Hedges LV, Gurevitch J, Curtis PS (1999) The meta-analysis of response ratios in experimental ecology. Ecology, 80, 1150-1156.

Hou YM, Pang XF, Liang GW, You MS (2001) Effect of chemical insecticides on the diversity of arthropods in vegetable fields. Acta Ecologica Sinica, 21, 1262-1268. (in Chinese with English abstract) [侯有明, 庞雄飞, 梁广文, 尤民生 (2001) 化学杀虫剂对菜田节肢动物多样性的影 响. 生态学报, 21, 1262-1268.]

Kolb S, Uzman D, Leyer I, Reineke A, Entling MH (2020) Differential effects of semi-natural habitats and organic management on spiders in viticultural landscapes. Agriculture, Ecosystems \& Environment, 287, 106695.

Kong J, Wang HY, Zhao BG, Ren YD, Liu YX, Chen HJ, Shan LN, Wang AC (2001) Study on ecological regulation system of the pest control in apple orchard. Acta Ecologica Sinica, 21, 789-794. (in Chinese with English abstract) [孔建, 王 海燕, 赵白鸽, 任应党, 刘玉霞, 陈汉杰, 单林娜, 王安 超 (2001) 苹果园主要害虫生态调控体系的研究. 生态 学报, 21, 789-794.]

Krauss J, Gallenberger I, Steffan-Dewenter I (2011) Decreased functional diversity and biological pest control in conventional compared to organic crop fields. PLoS ONE, 6, e19502.

Lei XD, Peng CH, Tian DL, Sun JF (2006) Meta-analysis and its application in global change. Chinese Science Bulletin, 51, 2587-2597. (in Chinese) [雷相东, 彭长辉, 田大伦, 孙 剑峰 (2006) 整合分析(meta-analysis)方法及其在全球变 化中的应用研究. 科学通报, 51, 2587-2597.]

Letourneau DK, Armbrecht I, Rivera BS, Lerma JM, Carmona EJ, Daza MC, Escobar S, Galindo V, Gutiérrez C, López SD, Mejía JL, Rangel AMA, Rangel JH, Rivera L, Saavedra 
CA, Torres AM, Trujillo AR (2011) Does plant diversity benefit agroecosystems? A synthetic review. Ecological Applications, 21, 9-21.

Li Q, Chen YQ, Guo X, Chen YL (2006) Arthropod used as bio-indicator to assess the success of ecological restoration. Journal of Central South Forestry University, 26, 117-122. (in Chinese with English abstract) [李巧, 陈又清, 郭萧, 陈彦林 (2006) 节肢动物作为生物指示物对生态恢复的 评价. 中南林学院学报, 26, 117-122.]

Lichtenberg EM, Kennedy CM, Kremen C, Batáry P, Berendse F, Bommarco R, Bosque-Pérez NA, Carvalheiro LG, Snyder WE, Williams NM, Winfree R, Klatt BK, Åström S, Benjamin F, Brittain C, Chaplin-Kramer R, Clough Y, Danforth B, Diekötter T, Eigenbrode SD, Ekroos J, Elle E, Freitas BM, Fukuda Y, Gaines-Day HR, Grab H, Gratton C, Holzschuh A, Isaacs R, Isaia M, Jha S, Jonason D, Jones VP, Klein AM, Krauss J, Letourneau DK, MacFadyen S, Mallinger RE, Martin EA, Martinez E, Memmott J, Morandin L, Neame L, Otieno M, Park MG, Pfiffner L, Pocock MJO, Ponce C, Potts SG, Poveda K, Ramos M, Rosenheim JA, Rundlöf M, Sardiñas H, Saunders ME, Schon NL, Sciligo AR, Sidhu CS, Steffan-Dewenter I, Tscharntke T, Veselý M, Weisser WW, Wilson JK, Crowder DW (2017) A global synthesis of the effects of diversified farming systems on arthropod diversity within fields and across agricultural landscapes. Global Change Biology, 23, 4946-4957.

Liu YF, Zhang GR, Gu DX (2000) Effect and the acting mechanisms of the habitats and vegetational diversity on arthropod community in agroecosystem. Journal of Xiangtan Normal University (Social Science Edition), 21(6), 74-78. (in Chinese) [刘雨芳, 张古忍, 古德祥 (2000) 农田生态 系统中生境与植被多样性对节肢动物群落的影响及其作 用机制探讨. 湘潭师范学院学报(社会科学版), 21(6), 74-78.]

Lu P, Mao NH, Liu B (2004) Core techniques and measures of plant protection in organic agriculture. China Plant Protection, 24(4), 36-39. (in Chinese) [陆萍, 冒乃和, 刘波 (2004) 有机农业植物保护的核心技术和措施. 中国植保 导刊, 24(4), 36-39.]

Mao RQ, Zhang WQ, Zhang GR, Gu DX (2000) Studies on the structure of egg-parasitoid community of rice planthopper in non-rice habitat. Natural Enemies of Insects, 22, 171-176. (in Chinese with English abstract) [毛润乾, 张文庆, 张古 忍, 古德祥 (2000) 非稻田生境中稻飞虫卵寄生蜂群落 结构研究. 昆虫天敌, 22, 171-176.]

Marshall J, Baudry J, Burel F, Joenje W, Gerowitt B, Paoletti M, Thomas G, Kleijn D, Le Coeur D, Moonen C (2002) Field boundary habitats for wildlife, crop, and environmental protection. In: Landscape Ecology in Agroecosystems Management (ed. Marshall J), pp. 219-248. CRC Press, Washington, D. C.

Moreby SJ, Aebischer NJ, Southway SE, Sotherton NW (1994)
A comparison of the flora and arthropod fauna of organically and conventionally grown winter wheat in southern England. Annals of Applied Biology, 125, 13-27.

Morente M, Campos M, Ruano F (2018) Evaluation of two different methods to measure the effects of the management regime on the olive-canopy arthropod community. Agriculture, Ecosystems \& Environment, 259, 111-118.

Pan Y, Xi YG, Tian W, Zhou KX, Chen QH, Gao JX (2020) Research status and hotspot analysis of international organic agriculture biodiversity research based on bibliometrics. Journal of Agro-Environment Science, 39, 1429-1441. (in Chinese with English abstract) [潘扬, 席运官, 田伟, 周可 新, 陈秋会, 高吉喜 (2020) 基于文献计量的国际有机农 业生物多样性研究现状与热点分析. 农业环境科学学报, 39, 1429-1441.]

Peng SL, Zheng FY (1999) Introduction of MetaWin software. Soil and Environmental Sciences, 8, 295-299. (in Chinese with English abstract) [彭少麟, 郑凤英 (1999) Meta分析 及MetaWin软件. 土壤与环境, 8, 295-299.]

Qian YQ, Ma KP (1994) Principles and Methods of Biodiversity Research. China Science \& Technology Press, Beijing. (in Chinese) [钱迎倩, 马克平 (1994) 生物多样性 研究的原理与方法. 中国科学技术出版社, 北京.]

Rosenberg MS, Adams DC, Gurevitch J (2000) Statistical Software for Meta-Analysis, version 2.0. Sinauer Associates, Sunderland, MA, USA.

State Administration for Market Regulation, China Agricultural University (2019) China Organic Product Certification and Organic Industry Development (2019). China Agricultural Science and Technology Press, Beijing. (in Chinese) [国家 市场监督管理总局, 中国农业大学 (2019) 中国有机产 品认证与有机产业发展(2019). 中国农业科学技术出版 社, 北京.]

Xing SW, Zhu H, Ma RJ, Du YQ, Sun YJ, Zha GC (2017) Effects of different habitats and management on the spider communities in tea plantations. Acta Ecologica Sinica, 37, 4236-4246. (in Chinese with English abstract) [邢树文, 朱 慧, 马瑞君, 杜颖青, 孙延杰, 查广才 (2017) 不同生境 条件与管理方式对茶园蜘蛛群落结构及多样性的影响. 生态学报, 37, 4236-4246.]

Yu XP, Hu C, Heong KL (1996) The effects of non-crop habitats on crop pests and their natural enemies. Chinese Journal of Biological Control, 12(3), 130-133. (in Chinese) [俞晓平, 胡萃, Heong KL (1996) 非作物生境对农业害虫 及其天敌的影响. 中国生物防治学报, 12(3), 130-133.]

Yuan W, Liu H, Zhang SX, Li WY (2010) Evaluation of communities of insect pests and natural enemies in organic rice fields of Changjiang Farm. Acta Agriculturae Shanghai, 26, 132-136. (in Chinese with English abstract) [袁伟, 刘 洪, 张士新, 黎伟裕 (2010) 长江农场有机稻田害虫与天 敌群落评价. 上海农业学报, 26, 132-136.]

Zhang QQ, Wang HS, Qin BR, Xie YL, Huang CY, Wang F, Wang KX (2014) Study on community structure and 
diversity of arthropods in ecological rice paddy fields. China Plant Protection, 34(4), 19-24. (in Chinese with English abstract) [张清泉, 王华生, 覃保荣, 谢义灵, 黄超燕, 王 峰, 王凯学 (2014) 生态稻田节肢动物群落结构及其多 样性研究. 中国植保导刊, 34(4), 19-24.]

Zhang R, Zhao ZH, He DH, Wang F, Zhang ZS, Wang XP (2010) The structure and dynamics of arthropod communities in Chinese wolfberry fields under different disturbances. Acta Ecologica Sinica, 30, 2656-2664. (in Chinese with English abstract) [张蓉, 赵紫华, 贺达汉, 王 芳, 张宗山, 王新谱 (2010) 不同干扰条件下枸杞园节肢 动物群落结构与动态. 生态学报, 30, 2656-2664.]
Zhang YX, Tang ZH (2005) Current status of arthropod resistance development. World Pesticide, 27(4), 1-6. (in Chinese) [张翼睘羽, 唐振华 (2005) 节肢动物抗药性发展 的现况. 世界农药, 27(4), 1-6.]

Zheng FY, Lu HF, Peng SL (2004) Non-parametric test for meta-analysis: Application of resampling tests. Ecology and Environment, 13, 616-618. (in Chinese with English abstract) [郑凤英, 陆宏芳, 彭少麟 (2004) 整合分析中的 非参数检验: 重复取样检验法的实例应用. 生态环境, 13, 616-618.]

(责任编委: 傅声雷 责任编辑: 闵文杰)

\section{附录 Supplementary Material}

附录1 本研究纳入的文献

Appendix 1 The literature included in the meta-analysis

https://www.biodiversity-science.net/fileup/PDF/2021243-1.pdf 
黄方倩, 王超, 刘明庆, 陈秋会, 韩笑, 王否, 席运官, 张纪兵 (2022) 有机种植对农田节肢动物多样性影响的整合分析. 生物多 样性, 30, 21243. https://www.biodiversity-science.net/CN/10.17520/biods.2021243

\section{附录1 本研究纳入的文献}

Appendix 1 The literature included in the meta-analysis

Alvarez T, Frampton GK, Goulson D (2001) Epigeic Collembola in winter wheat under organic, integrated and conventional farm management regimes. Agriculture, Ecosystems \& Environment, 83, 95-110.

Caprio E, Nervo B, Isaia M, Allegro G, Rolando A (2015) Organic versus conventional systems in viticulture: Comparative effects on spiders and carabids in vineyards and adjacent forests. Agricultural Systems, 136, 61-69.

Chen HF, Li KS, Yu P, Huang JH (2015) Analysis on arthropod community structure parameters in paddy fields by the yellow board trap sampling. Journal of Shanxi Agricultural University (Natural Science Edition), 35, 447-450. (in Chinese with English abstract) [陈洪凡, 李快生, 余鹏, 黄建华 (2015) 黄板诱集法取样下稻田节肢动物群落结构特征参数分析. 山 西农业大学学报(自然科学版), 35, 447-450.]

Chen HF, Liang YY, Ye DP, Lan B, Li XM, Yang YQ (2017) Analysis of the arthropod community composition in paddy fields by sweep net sampling. Journal of Anhui Agricultural University, 44, 1124-1130. (in Chinese with English abstract) [陈洪 凡, 梁玉勇, 叶德萍, 兰波, 李湘民, 杨迎青 (2017) 扫网法取样下稻田节肢动物群落组成分析. 安徽农业大学学报, 44, 1124-1130.]

Doles JL, Zimmerman RJ, Moore JC (2001) Soil microarthropod community structure and dynamics in organic and conventionally managed apple orchards in Western Colorado, USA. Applied Soil Ecology, 18, 83-96.

Drinkwater LE, Letourneau DK, Workneh F, van Bruggen AHC, Shennan C (1995) Fundamental differences between conventional and organic tomato agroecosystems in California. Ecological Applications, 5, 1098-1112.

Dritschilo W, Erwin TL (1982) Responses in abundance and diversity of cornfield carabid communities to differences in farm practices. Ecology, 63, 900-904.

Dritschilo W, Wanner D (1980) Ground beetle abundance in organic and conventional corn fields. Environmental Entomology, 9, 629-631.

Feber RE, Bell J, Johnson PJ, Firbank LG, MacDonald DW (1998) The effects of organic farming on surface-active spider (Araneae) assemblages in wheat in southern England, UK. Journal of Arachnology, 26, 190-202.

Froidevaux JSP, Louboutin B, Jones G (2017) Does organic farming enhance biodiversity in Mediterranean vineyards? A case study with bats and arachnids. Agriculture, Ecosystems \& Environment, 249, 112-122.

Gkisakis V, Volakakis N, Kollaros D, Bàrberi P, Kabourakis EM (2016) Soil arthropod community in the olive agroecosystem: Determined by environment and farming practices in different management systems and agroecological zones. Agriculture, Ecosystems \& Environment, 218, 178-189.

Gu SS, Hu QL, Gong ZH, Yang ZX, Li J, Tan L (2019) Community structure of arthropods in tea plantations under different management modes. Guizhou Agricultural Sciences, 47, 31-35. (in Chinese with English abstract) [顾松松, 胡秋龙, 龚志 华, 杨中侠, 李娟, 谭琳 (2019) 不同管理模式下茶园节肢动物的群落结构. 贵州农业科学, 47, 31-35.]

Hadjicharalampous E, Kalburtji KL, Mamolos AP (2002) Soil arthropods (Coleoptera, Isopoda) in organic and conventional agroecosystems. Environmental Management, 29, 683-690.

Han BY (2005) Difference in dynamic and structure of spider communities in organic and non-pollution and common tea gardens. Acta Arachnologica Sinica, 14, 104-107. (in Chinese with English abstract) [韩宝瑜 (2005) 有机、无公害和普通茶园蜘 蛛群落组成及动态差异. 蛛形学报, 14, 104-107.] 
黄方倩, 王超, 刘明庆, 陈秋会, 韩笑, 王否, 席运官, 张纪兵 (2022) 有机种植对农田节肢动物多样性影响的整合分析. 生物多 样性, 30, 21243. https://www.biodiversity-science.net/CN/10.17520/biods.2021243

Han BY, Cui L, Dong WX (2006) The effect of farming methods in organic, safety, and common tea gardens on the composition of arthropod communities and the abundances of main pests. Acta Ecologica Sinica, 26, 1438-1443. (in Chinese with English abstract) [韩宝瑜, 崔林, 董文霞 (2006) 有机、无公害和普通茶园管理方式对节肢动物群落和主要害虫的影响. 生态 学报, 26, 1438-1443.]

Han BY, Zhou P, Cui L, Zhou XG, Xia Y (2007) Impact of farming methods and tea garden habitats on population density of Ectropis oblique and its main natural enemies. Acta Phytophylacica Sinica, 34, 15-21. (in Chinese with English abstract) [韩 宝瑜, 周鹏, 崔林, 周孝贵, 夏艳 (2007) 不同管理方式的茶园生境中茶尺蠖及其天敌密度的差异. 植物保护学报, 34, 15-21.]

Han Y, Dai PP, Li X, Song X, Li J, Liu YH (2015) Effects of organic farming on diversity of arthropods in farmlands of North China plain in summer. Journal of Ecology and Rural Environment, 31, 697-703. (in Chinese with English abstract) [韩印, 戴漂漂, 李想, 宋潚, 李季, 刘云慧 (2015) 华北平原有机农业对夏季农田节肢动物多样性的影响. 生态与农村环境 学报, 31, 697-703.]

Hesler LS, Grigarick AA, Oraze MJ, Palrang AT (1993) Arthropod fauna of conventional and organic rice fields in California. Journal of Economic Entomology, 86, 149-158.

Hou YM, Pang XF, Liang GW, You MS (2001) Effect of chemical insecticides on the diversity of arthropods in vegetable fields. Acta Ecologica Sinica, 21, 1262-1268. (in Chinese with English abstract) [侯有明, 庞雄飞, 梁广文, 尤民生 (2001) 化学 杀虫剂对菜田节肢动物多样性的影响. 生态学报, 21, 1262-1268.]

Huang XC (2011) Arthropod biodiversity in paddy fields under different management regimes. Master dissertation, Nanjing Agricultural University, Nanjing. (in Chinese with English abstract) [黄先才 (2011) 不同管理模式稻田节肢动物多样性 研究. 硕士学位论文, 南京农业大学, 南京.]

Huang ZE, Du XG, Dong M, Yang DP, Zhang LD (2004) Effects of organic management on the stability of arthropods in organic tea gardens. Chinese Agricultural Science Bulletin, 20, 57-59, 98. (in Chinese with English abstract) [黄正恩, 杜相革, 董 民，杨东鹏，张禄达 (2004) 有机管理对茶园节肢动物群落稳定性的影响. 中国农学通报, 20, 57-59, 98.]

Isaia M, Bona F, Badino G (2006) Influence of landscape diversity and agricultural practices on spider assemblage in Italian vineyards of langa astigiana (northwest Italy). Environmental Entomology, 35, 297-307.

Kolb S, Uzman D, Leyer I, Reineke A, Entling MH (2020) Differential effects of semi-natural habitats and organic management on spiders in viticultural landscapes. Agriculture, Ecosystems \& Environment, 287, 106695.

Krauss J, Gallenberger I, Steffan-Dewenter I (2011) Decreased functional diversity and biological pest control in conventional compared to organic crop fields. PLoS ONE, 6, e19502.

Letourneau DK, Goldstein B (2001) Pest damage and arthropod community structure in organic vs. conventional tomato production in California. Journal of Applied Ecology, 38, 557-570.

Li H (2010) The comparison of arthropod community structure and diversity between the organic orchard and non-organic orchard. Master dissertation, Tianjin Normal University, Tianjin. (in Chinese with English abstract) [李浩 (2010) 有机果园与非有 机果园节肢动物群落结构及多样性比较. 硕士学位论文, 天津师范大学, 天津.]

Li ZQ, Liang GW, Cen YJ, Zeng L (2009) Roles of organic management in restoration of arthropod community diversity in Citrus orchard. Chinese Journal of Ecology, 28, 1515-1519. (in Chinese with English abstract) [李志强, 梁广文, 岑伊静, 曾玲 (2009) 有机管理对柑橘园节肢动物群落多样性恢复的作用. 生态学杂志, 28, 1515-1519.]

Lin J, Zou W, Wang SJ, Lin NQ (2008) A preliminary investigation on the arthropod community at three plantations in Fu'an. Entomological Journal of East China, 17, 194-199. (in Chinese with English abstract) [林瑾, 邹武, 王水金, 林乃铨 (2008) 
黄方倩, 王超, 刘明庆, 陈秋会, 韩笑, 王否, 席运官, 张纪兵 (2022) 有机种植对农田节肢动物多样性影响的整合分析. 生物多 样性, 30, 21243. https://www.biodiversity-science.net/CN/10.17520/biods.2021243

福安三种不同茶园节肢动物群落的消长动态调查. 华东昆虫学报, 17, 194-199.]

Liu JH (2017) Contrasting arthropod communities in wolfberry orchards of different management regimes in northwestern China. Pakistan Journal of Agricultural Sciences, 54, 595-605.

Mao M, Zhang X, Wang L, Xiao XJ, Wang H, Li HX, Jiao JG, Wang X (2019) Survey on soil fauna diversity under organic farming. Soils, 51, 698-707. (in Chinese with English abstract) [毛妙，张欣，王否，肖兴基，王辉，李辉信，焦加国，王霞 (2019) 有机种植模式土壤动物多样性的调查研究. 土壤, 51, 698-707.]

Moreby SJ, Aebischer NJ, Southway SE, Sotherton NW (1994) A comparison of the flora and arthropod fauna of organically and conventionally grown winter wheat in southern England. Annals of Applied Biology, 125, 13-27.

Morente M, Campos M, Ruano F (2018) Evaluation of two different methods to measure the effects of the management regime on the olive-canopy arthropod community. Agriculture, Ecosystems \& Environment, 259, 111-118.

Pang DH, Xiao RL, Hou BH, Shan WX, Chen P (2010) Effect of ecological management on arthropod community structure and diversity in hilly tea plantation. Chinese Journal of Eco-Agriculture, 18, 1272-1276. (in Chinese with English abstract) [庞冬 辉, 肖润林, 侯柏华, 单武雄, 陈佩 (2010) 生态管理对茶园节肢动物群落结构和多样性的影响. 中国生态农业学报, 18, 1272-1276.]

Pfiffner L, Luka H (2003) Effects of low-input farming systems on carabids and epigeal spiders - A paired farm approach. Basic and Applied Ecology, 4, 117-127.

Pfiffner L, Niggli U (1996) Effects of bio-dynamic, organic and conventional farming on ground beetles (Col. Carabidae) and other epigaeic arthropods in winter wheat. Biological Agriculture \& Horticulture, 12, 353-364.

Ponce C, Bravo C, León DGD, Magaña M, Alonso JC (2011) Effects of organic farming on plant and arthropod communities: A case study in Mediterranean dryland cereal. Agriculture, Ecosystems \& Environment, 141, 193-201.

Ruano F, Lozano C, Garcia P, Pena A, Tinaut A, Pascual F, Campos M (2004) Use of arthropods for the evaluation of the oliveorchard management regimes. Agricultural and Forest Entomology, 6, 111-120.

Rubens PDB, Ligia SR, Isabelle CSM, Miriany DOP, Ana CBDL, Claudio GDS, Jaciara MPES, João GDC, Elio CG (2018) Diversity of insects in conventional and organic tomato crops (Solanum lycopersicum L., Solanaceae). African Journal of Agricultural Research, 13, 460-469.

Santos LAOD, Naranjo-Guevara N, Fernandes OA (2017) Diversity and abundance of edaphic arthropods associated with conventional and organic sugarcane crops in Brazil. Florida Entomologist, 100, 134-144.

Santos SAP, Pereira JA, Torres LM, Nogueira AJA (2007) Evaluation of the effects, on canopy arthropods, of two agricultural management systems to control pests in olive groves from north-east of Portugal. Chemosphere, 67, 131-139.

Sean Clark M (1999) Ground beetle abundance and community composition in conventional and organic tomato systems of California's Central Valley. Applied Soil Ecology, 11, 199-206.

Tan JC, Deng X, Yuan ZM (1998) Community structure of insects and spiders in different types of tea plantation. Acta Ecologica Sinica, 18, 289-294. (in Chinese with English abstract) [谭济才，邓欣，袁哲明 (1998) 不同类型茶园昆虫、蜘蛛群落结 构分析. 生态学报, 18, 289-294.]

Vitanović E, Ivezić M, Kačić S, Katalinić M, Durbešić P, Igrc Barčić J (2018) Arthropod communities within the olive canopy as bioindicators of different management systems. Spanish Journal of Agricultural Research, 16, e0301. DOI:10.5424/sjar/2018162-12385.

Wang CY, Wang G, Wan SW, Qin P (2007) Effects of organic and conventional farming systems on farmland biodiversity. Journal of Ecology and Rural Environment, 23, 75-80. (in Chinese with English abstract) [王长永, 王光, 万树文, 钦佩 (2007) 有 
黄方倩, 王超, 刘明庆, 陈秋会, 韩笑, 王否, 席运官, 张纪兵 (2022) 有机种植对农田节肢动物多样性影响的整合分析. 生物多 样性, 30, 21243. https://www.biodiversity-science.net/CN/10.17520/biods.2021243

机农业与常规农业对农田生物多样性影响的比较研究进展. 生态与农村环境学报, 23, 75-80.]

Wang L, Li G, Xi YG, Chen QH, Li Y, Tian W, Zhang C, Li P, Yang H, Zhang JB, Xiao XJ (2018) Investigation on animal diversity in different paddy fields with organic farming: A case study in Daizhuang of Jurong County, Jiangsu Province, China. Journal of Ecology and Rural Environment, 34, 614-621. (in Chinese with English abstract) [王磊, 李刚, 席运官, 陈秋会, 李妍, 田伟, 张弛, 李鹏, 杨豪, 张纪兵, 肖兴基 (2018) 有机种植方式对稻田动物多样性的影响: 以句容戴庄为例. 生态与农村环境学报, 34, 614-621.]

Wang XW, Ding XH, Tu EX, Fu KY, He J, Ban XL, Fu WJ, Guan ZJ, Liu W, Guo WC (2017) The structure and diversity of arthropod communities in paddy fields under different management models in Yili river valley. Xinjiang Agricultural Sciences, 54, 1875-1886. (in Chinese with English abstract) [王小武, 丁新华, 吐尔逊, 付开望, 何江, 班小莉, 付文君, 关志坚, 刘文, 郭文超 (2017) 伊犁河谷不同管理模式稻田节肢动物群落结构及多样性. 新疆农业科学, 54, 1875-1886.]

Xing SW, Zhu H, Ma RJ, Du YQ, Sun YJ, Zha GC (2017) Effects of different habitats and management on the spider communities in tea plantations. Acta Ecologica Sinica, 37, 4236-4246. (in Chinese with English abstract) [邢树文, 朱慧, 马瑞君, 杜颖 青, 孙延杰, 查广才 (2017) 不同生境条件与管理方式对茶园蜘蛛群落结构及多样性的影响. 生态学报, 37, 42364246.]

Yang GQ, Wu JC, Zhang SX, Zhang JH, Yang YQ, Wang HQ (2004) The relationship among structures, intrinsic rate of increase of functional guilds, and link numbers of arthropod community in three types of rice field under organic rice production system. Acta Ecologica Sinica, 24, 686-692. (in Chinese with English abstract) [杨国庆, 吴进才, 张士新, 张建汉, 杨衍 强, 王洪全 (2004) 三种类型稻田节肢动物群落结构、亚群落内禀增长率与链节数的关系. 生态学报, 24, 686-692.]

Zeng LB, Cheng Y, Yan Z, Ma J, Ren SX, Wei L, Xue ZD (2016) Effects of different control strategies on the structure of the arthropod community in the cauliflower field. Scientia Agricultura Sinica, 49, 2965-2976. (in Chinese with English abstract) [曾粮斌, 程毅, 严准, 马骏, 任顺祥, 魏林, 薛召东 (2016) 不同防治措施对花椰菜地节肢动物群落结构的影响. 中 国农业科学, 49, 2965-2976.]

Zeng MS, Wu GY, Wang QS, Yu SH (2008) Preliminary study on Fujian's spider species and their community population fluctuation in tea plantations. Guizhou Science, 26, 34-38. (in Chinese with English abstract) [曾明森, 吴光远, 王庆森, 余 素红 (2008) 福建茶园蜘蛛种类与种群动态的初步研究. 贵州科学, 26, 34-38.]

Zeng ZA, Liang GW (2008) The impact of different management methods on arthropod community in litchi orchards. Journal of Environmental Entomology, 30, 16-21. (in Chinese with English abstract) [曾赞安, 梁广文 (2008) 不同管理方式下荔枝 园节肢动物群落的调查. 环境昆虫学报, 30, 16-21.]

Zhang R, Zhao ZH, He DH, Wang F, Zhang ZS, Wang XP (2010) The structure and dynamics of arthropod communities in Chinese wolfberry fields under different disturbances. Acta Ecologica Sinica, 30, 2656-2664. (in Chinese with English abstract) [张 蓉, 赵紫华, 贺达汉, 王芳, 张宗山, 王新谱 (2010) 不同干扰条件下枸杞园节肢动物群落结构与动态. 生态学报, 30, 2656-2664.]

Zhong J, Dai LD, Mao JH, Yao L, Chen Y (2016) A study of insect pests and natural enemies in different tea gardens in Mingshan. Journal of Sichuan Forestry Science and Technology, 37, 97-101. (in Chinese with English abstract) [钟金, 代立东, 毛建 辉, 姚琳, 陈宇 (2016) 名山不同类型茶园害虫及天敌研究. 四川林业科技, 37, 97-101.]

Zhou ZY (2011) Arthropod diversity in non-crop habitats at margins of paddy fields of different types. Master dissertation, Nanjing Agricultural University, Nanjing. (in Chinese with English abstract) [周子杨 (2011) 不同类型稻田非作物生境的节肢动 物多样性. 硕士学位论文, 南京农业大学, 南京.] 